East African Medical Journal Vol. 77 No. 9 September 2000

SOCIO-ECONOMIC RISK FACTORS FOR SEVERE PROTEIN ENERGY MALNUTRITION AMONG CHILDREN IN MULAGO HOSPITAL, KAMPALA

M. Owor, MBChB., MMed., J. K. Tumwine, MBChB., MMed., FRSH, Associate Professor, Department of Paediatrics and Child Health, Makerere University Medical

School and J. K. Kikafunda, MSc., PhD., Department of Food Science and Technology, Makerere University, P.O. Box 7072, Kampala, Uganda

Request for reprints to: Professor J. K. Tumwine, Department of Paediatrics and Child Health, Makerere University Medical School, P O Box 7072, Kampala, Uganda.

\title{
SOCIO-ECONOMIC RISK FACTORS FOR SEVERE PROTEIN ENERGY MALNUTRITION AMONG CHILDREN IN MULAGO HOSPITAL, KAMPALA
}

\author{
M. OWOR, J. K. TUMWINE and J. K. KIKAFUNDA
}

\begin{abstract}
Background: Despite Uganda's recent economic success, malnutrition is still an important public health problem and little information is available on socio-economic risk factors for severe protein energy malnutrition.

Objective: To determine socio-economic risk factors for severe protein energy malnutrition among children aged 0-60 months.

Design: A case control study.

Setting: Mulago Referral and Teaching Hospital, Kampala, Uganda.

Patients: Sixty six severely malnourished children (age 0-60 months) were matched, for age and sex, with 66 well nourished controls, and socio-economic, demographic, health facility utilisation and feeding practices were compared between the two groups.

Results: Severe protein energy malnutrition was associated with young age of the caretaker $(p=0.005)$, living in a mud walled house (OR 2.44, CI 1.13 - 5.32), lack of breast feeding (OR 3.22, CI 1.31- 8.02), failure to complete immunisation (OR 3.68, CI 1.53 - 9.011), no land ownership (OR 4.62, CI 2.09 - 10.3), and no ownership of livestock (OR 13.65, CI 3.60 - 60.84), by the caretaker. The level of formal education of the caretaker was not associated with severe malnutrition.

Conclusion: There seems to be a strong association between severe malnutrition and some indicators of poverty, lack of breastfeeding, and failure to complete immunisation. Programmes aimed at poverty alleviation, promotion of breastfeeding and immunisation, will go a long way in preventing malnutrition.
\end{abstract}

\section{INTRODUCTION}

Despite Uganda's impressive political and economic recovery, child malnutrition is still a serious problem: $37 \%$ of underfives suffer from stunting and $23 \%$ are wasted(1). The prevalence of kwashiorkor and marasmus in Uganda seems to be on the increase(2) while $40 \%$ of infant deaths are attributable to malnutrition alone(3). Moderate forms of malnutrition account for $34 \%$ of the infant deaths, while severe forms of malnutrition account for the remaining six per cent. The effects of malnutrition and infection on children are synergistic and their combined effect on child mortality can be devastating(4-6). Severe malnutrition has other adverse consequences which include severity of illness, lower cognitive development, and poor pregnancy outcomes in later life $(7,8)$.

Although factors predisposing children to the non severe forms of protein energy malnutrition have been studied $(2,9)$, there is a dearth of information on socioeconomic factors amongst children with severe forms of malnutrition. This paper reports results of a study of socioeconomic risk factors for severe protein energy malnutrition amongst children attending Mulago National Referral and Teaching Hospital in Uganda, between October 1997 and January 1998. The general objective of the study was to determine the socio-economic factors associated with severe forms of protein energy malnutrition among children attending Mulago Hospital. The specific objectives were to compare feeding practices, health facility utilisation, and socio-demographic characteristics of mothers or caretakers of malnourished children with those of mothers or caretakers of well nourished children.

\section{MATERIALS AND METHODS}

Patients/study population: The study population included 0-60 months old children attending Mulago Hospital with a diagnosis of severe protein energy malnutrition (kwashiorkor, marasmus, or marasmus, according to the Wellcome classification(10)) and their caretakers/mothers.

Study design: This was a case control study in which malnourished children (cases) were matched for age and sex with well nourished children (controls). The controls consisted of children aged 0-60 months without malnutrition (weight for age greater than $80 \%$ of the standard, with neither oedema nor other signs of malnutrition), and their caretakers/mothers.

Inclusion criteria: Children aged 0-60 months with severe protein energy malnutrition, according to the Wellcome classification(10), with their caretakers/mothers were recruited into the study as cases. Controls included children aged 0-60 months matched for age and sex to the cases, and attending Mulago Hospital paediatric emergency ward (Acute Care Unit) 
or the out-patient unit (Mulago Hill Dispensary) with their mothers/caretakers, who gave informed consent. The weight for age of the control children had to be greater than $80 \%$ of the standard(10) without oedema.

Exclusion criteria: Children whose mothers/caretakers had not been staying with them within six months prior to the study, or those with cancer or any physical or mental condition predisposing them to malnutrition, were excluded from the study.

Ethical issues: Permission to carry out the study was obtained from the Department of Paediatrics and Child Health, Makerere Medical School, the Makerere Faculty of Medicine Research Committee, and Mulago Hospital. Written consent was obtained from the mothers/caretakers after explaining to them the objectives of the study, and all information collected on each individual was held in confidence.

Sampling and sample size: Malnourished children who fulfilled the selection criteria were consecutively enrolled into the study. They were matched with well nourished controls of similar age and sex. The controls were recruited with the help of the attendance register of the unit (Acute Care Unit or Mulago Hill Dispensary) from where the case was first seen. If there were more than two well nourished children suitable as controls, one of them was chosen using simple random sampling(11). All the cases and controls were assigned identification numbers and their files/hospital records tagged to avoid double recruitment.

Sample size calculation was based on our knowledge of the formal education level of mothers in Kampala(1). We chose a power of $80 \%$ and 2-tailed levels of significance of 5\% (95\% confidence interval). Assuming $75 \%$ of control mothers/ caretakers were educated, and only $50 \%$ of the mothers/caretakers of the cases were educated(1), a sample size of 132 children (66 cases and 66 controls) was calculated using the method and formulae developed by Fleiss(12).

Measurements: Weight: Children were weighed using United Nations guidelines(13). The children were weighed nude to the nearest $100 \mathrm{~g}$ using a $25 \mathrm{~kg}$ scale (Salter Weight-Tronix Ltd, West Bromwich, West Midlands, UK) which was checked with a standard weight at the beginning of each day's session and adjusted accordingly. The pointer on the scale was adjusted to zero with a weighing sling attached before each child was weighed. Each weight was dictated by one of us (MO.) to a recorder who repeated it aloud after writing it down.
Length/height: Height for children aged 24 - 60 months, and length for those below two years was measured using a stadiometer constructed according to United Nations specifications. Height was taken to the nearest 0.1 centimetre. Children below two years of age were made to lie on the stadiometer with the lower limbs extended. The head was made to lie at the zero end and the reading was taken at the heels using a sliding board.

Heights were measured by making the child to stand on the stadiometer with heels against the board, feet flat and small board placed at the highest point on the head. A questionnaire which was validated by the jury method(14), was pilot tested before the study on children in a similar setting. The questionnaires were administered to the mothers or caretakers by one of us (M.O) or by an assistant trained to ask the questions in a local language.

The age of the children was ascertained, to the nearest month, through birth or baptismal certificates, health record cards, or through a calendar of local events like the last general election.

Statistical analysis. Data was entered into a computerised database using CDC/WHO computer software Epi Info(15). Written informed consent was obtained from the mothers/ caretakers after explaining to them the objectives of the study. Analysis involved cross tabulations and odds ratios with their associations. Confidence intervals (95\%) were obtained using categorical variables, and the Pearson Chi-squared test was used to ascertain statistical significance for categorical variables. Comparison of continuous variables was done by comparing means, and tests for significance using the $\mathrm{t}$ - test.

\section{RESULTS}

One hundred and thirty two children were studied, of whom 66 were severely malnourished and 66 were well nourished controls. Apart from nutrition status, and area of residence, the two groups were similar (Table 1).

Among the socio-demographic characteristics of the care takers and mothers of the cases and controls, only age was statistically different (Table 2). On average the control mothers/caretakers were four years older than the mothers/ caretakers of the cases.

Table 1

Some baseline characteristics of severely malnourished and well nourished children (controls)

\begin{tabular}{|c|c|c|c|c|c|}
\hline Variable & Cases $(n=66)$ & Controls $(n=66)$ & $\mathrm{P}$ value & $\begin{array}{l}\text { Odds } \\
\text { ratio }\end{array}$ & $\begin{array}{l}95 \% \\
\text { confidence interval }\end{array}$ \\
\hline \multicolumn{6}{|l|}{$\operatorname{Sex}$} \\
\hline Male & 37 & 37 & 0.86 & 1.0 & $0.47-2.11$ \\
\hline Female & 29 & 29 & & & \\
\hline \multicolumn{6}{|l|}{ Ethnic origin } \\
\hline Ganda & $45(68 \%)$ & $48(73 \%)$ & 0.70 & 0.8 & $0.35-1.82$ \\
\hline Others & $21(32 \%)$ & $18(27 \%)$ & & & \\
\hline \multicolumn{6}{|l|}{ Area of residence } \\
\hline Urban & 58 & 46 & $0.02 *$ & 3.15 & $1.2-8.6$ \\
\hline \multirow[t]{2}{*}{ Rural } & 8 & 20 & & & \\
\hline & Mean (range) & Mean (range) & & & \\
\hline Age (months) & $20.1(5-60)$ & $20.6(6-60)$ & 0.8 & - & - \\
\hline Weight for age $\%$ & $62.0(4-80)$ & $90.1(81-120)$ & $0.00 *$ & - & - \\
\hline Height for age $\%$ & $71.2(59-105)$ & $78.4(60-123)$ & $0.00 *$ & - & - \\
\hline
\end{tabular}

* p value significant 
Table 2

Socio-demographic characteristics of the caretakers/mothers of well nourished and severely malnourished children, Mulago Hospital

\begin{tabular}{|c|c|c|c|c|c|}
\hline Variable & Cases $(n=66)$ & Controls $(n=66)$ & $\mathrm{p}$ value & $\begin{array}{l}\text { Odds } \\
\text { ratio }\end{array}$ & $\begin{array}{l}95 \% \\
\text { Confidence interval }\end{array}$ \\
\hline \multicolumn{6}{|l|}{ Sex } \\
\hline Male (\%) & $3(4.5)$ & $1(1.5)$ & 0.61 & - & - \\
\hline Female $(\%)$ & $63(95.5)$ & $65(98.5)$ & & & \\
\hline \multicolumn{6}{|l|}{ Marital status } \\
\hline Married (\%) & $54(81.8)$ & $58(87.8)$ & 0.47 & 0.62 & $0.21-1.79$ \\
\hline \multicolumn{5}{|l|}{ Single/ } & \\
\hline \multicolumn{6}{|l|}{ Relation to child } \\
\hline Mother & 59 & 56 & 0.06 & 1.51 & $0.48-4.76$ \\
\hline Other & 7 & 10 & & & \\
\hline \multicolumn{6}{|l|}{ Education level } \\
\hline Nil (\%) & $6(9.1)$ & $7(10.1)$ & 0.92 & - & - \\
\hline Primary (\%) & $34(51.5)$ & $35(53.0)$ & & & \\
\hline Secondary (\%) & $26(39.4)$ & $24(36.4)$ & & & \\
\hline \multicolumn{6}{|l|}{ Occupation } \\
\hline Unemployed (\%) & $56(84.8)$ & $51(77.3)$ & 0.51 & - & - \\
\hline Trader $(\%)$ & $6(9.1)$ & $10(15.2)$ & & & \\
\hline \multirow[t]{2}{*}{ Professional (\%) } & $4(6.1)$ & $5(7.6)$ & & & \\
\hline & mean (Range) & Mean (Range) & & & \\
\hline Age in years & $24.1(15-50)$ & $28.3(17-75)$ & $0.01 *$ & - & - \\
\hline
\end{tabular}

* p value significant

Table 3

Nutrition knowledge of mothers/caretakers of malnourished and well nourished children

\begin{tabular}{lllc}
\hline Variable & Cases (n=66) & Controls (n=66) & pvalue \\
\hline $\begin{array}{l}\text { Recommended age } \\
\text { (weaning in months) }\end{array}$ & $\begin{array}{l}\text { Mean (range) } \\
4.78(0-25)\end{array}$ & $\begin{array}{l}\text { Mean (range) } \\
4.44(0-20)\end{array}$ & 0.59 \\
$\begin{array}{l}\text { Duration of breast } \\
\text { feeding (months) }\end{array}$ & $23.54(12-36)$ & $22.30(2-36)$ & 0.08 \\
$\begin{array}{l}\text { Frequency } \\
\text { of feeding per 24 h }\end{array}$ & $3.54(1-10)$ & $3.28(1-6)$ & 0.82 \\
\hline
\end{tabular}

The nutrition knowledge of caretakers /mothers of the cases and of the controls was not statistically different (Table 3).

Of the 50 cases aged $0-23$ months, only 15 (50\%) were still breastfeeding while 29 (58\%) of the 50 controls in the same age group were still breast feeding. Lack of breast feeding was a risk factor for malnutrition (odds ratio $3.222,95 \%$ confidence intervals $1.31-8.02, \mathrm{p}=0.009$ ).

Table 4

\begin{tabular}{|c|c|c|c|c|c|}
\hline Variable & $\begin{array}{l}\text { Cases } \\
(n=66)\end{array}$ & $\begin{array}{l}\text { Controls } \\
(n=66)\end{array}$ & $\begin{array}{l}\text { Odds } \\
\text { ratio }\end{array}$ & $\begin{array}{l}95 \% \\
\text { confidence } \\
\text { intervals }\end{array}$ & $\mathrm{p}$ value \\
\hline Place of delivery & 8 & 17 & & & \\
\hline $\begin{array}{l}\text { Home health unit } \\
\text { Immunisation status }\end{array}$ & 57 & 49 & 0.4 & $0.14-1.10$ & 0.082 \\
\hline Completed & 38 & 55 & & & \\
\hline Not completed & 28 & 11 & 3.68 & $1.53-9.01$ & $0.0023 *$ \\
\hline
\end{tabular}

* p value significant
Table 5

Economic status of the caretakers/mothers of severely malnourished and well nourished children

\begin{tabular}{lcllll}
\hline Variable & $\begin{array}{l}\text { Cases } \\
(\mathrm{n}=66)\end{array}$ & $\begin{array}{l}\text { Controls } \\
(\mathrm{n}=66)\end{array}$ & $\begin{array}{l}\text { Odds } \\
\text { ratio }\end{array}$ & $\begin{array}{l}95 \% \\
\text { confidence } \\
\text { intervals }\end{array}$ & P value \\
\hline $\begin{array}{l}\text { House ownership } \\
\text { Yes }\end{array}$ & 28 & 30 & & & \\
No & 38 & 36 & 1.13 & $0.54-2.39$ & 0.86 \\
$\begin{array}{l}\text { Type of roof } \\
\text { Metal }\end{array}$ & 52 & 55 & & & \\
Thatch & 14 & 11 & 0.74 & $0.28-1.94$ & 0.66 \\
$\begin{array}{l}\text { Type of wall } \\
\text { Mud }\end{array}$ & 46 & 32 & & & \\
Concrete & 20 & 34 & 2.44 & $1.13-5.32$ & $0.02 *$ \\
$\begin{array}{l}\text { Radio ownership } \\
\text { Yes }\end{array}$ & 56 & 54 & 1.24 & & \\
No & 10 & 12 & 1.24 & $0.45-3.43$ & 0.82 \\
$\begin{array}{l}\text { Ownership of cows } \\
\text { Yes }\end{array}$ & 2 & 26 & & & \\
No & 63 & 40 & 13.67 & $3.60-60.84$ & $0.00^{*}$ \\
$\begin{array}{l}\text { Ownership of goats } \\
\text { Yes }\end{array}$ & 4 & 14 & & & \\
No & 62 & 52 & 5.17 & $1.45-20.14$ & $0.01^{*}$ \\
$\begin{array}{l}\text { Land ownership } \\
\text { Yes }\end{array}$ & 43 & 19 & & & $0.00^{*}$ \\
No & 23 & 47 & 4.62 & $2.09-10.3$ & \\
\hline & & & & & \\
\hline
\end{tabular}

* p value significant

There was a thirteen fold risk of malnutrition in children whose mothers/caretakers owned no cows. While children whose mothers/caretakers owned no land had a 4.6 risk of malnutrition compared to the controls, the corresponding risk factor for malnutrition for children living in mud walled houses was 2.4 compared with children living in houses with concrete walls. 


\section{DISCUSSION}

In this study we have explored some socio-economic factors associated with severe forms of protein energy malnutrition in children admitted to Mulago Teaching Hospital in Kampala, Uganda.

Surprisingly, there was no correlation between the formal education level of the mothers/caretakers and nutrition status of the children $(\mathrm{p}=0.92)$. This finding is different from the results of several studies from Uganda $(9,16)$ which found a positive association between mothers' education and stunting of their children. However these studies did not investigate severe forms of protein energy malnutrition. The lack of a significant association between the mothers' education and children's nutrition status is in agreement with Nhembe and Waterston's study of causes of severe malnutrition in Harare, Zimbabwe(17). A similar study in Nigeria(18) showed that despite high education levels of the mothers, their children still had severe forms of malnutrition. It would appear that the impact of mothers' education on nutrition status is through its ability to improve socio-economic status, health facility utilisation and greater involvement of mothers in decisions regarding child care $(19,20)$.

In the current study, coming from an urban setting was associated with severe forms of malnutrition (odds ratio $3.15,95 \%$ confidence interval $1.18-8.64, \mathrm{p}=0.02$ ), and, in fact, all the malnourished urban children came from slum areas in Kampala. However, this might indicate a selection bias since residence (rural or urban) was not controlled for. Despite this shortcoming, it is apparent that there is a population of children in Kampala city who are at risk of malnutrition. In fact several studies $(21,22)$ have shown that even within cities, malnutrition abounds.

In this study, children with severe malnutrition came from families with low socio-economic status. For example $70 \%$ of the severely malnourished children lived in mud walled houses compared to only $48 \%$ in the well nourished group (odds ratio $2.44,95 \%$ confidence intervals 1.13 $5.32, \mathrm{p}=0.02$ ), a finding consistent with other studies from Bangladesh, Zambia and Nigeria(21-24). Only 5\% of the households with severely malnourished children owned livestock compared with $40 \%$ of households with well nourished controls. Vella and Tomkin's study(25) in south west Uganda also established that children from households with no livestock were at higher risk of malnutrition.

The other important economic determinant of severe malnutrition seems to be lack of land ownership. Sixty per cent of severely malnourished children in the current study came from landless households, while only $28 \%$ of the well nourished children came from such households (odds ratio 4.62, 95\% confidence intervals 2.09-10.3, $\mathrm{p}=0.00)$. This finding is consistent with similar findings from Zimbabwe(26), Malawi(27) and south western Uganda(25), all of which have consistently shown that children from landless households or those from households with very small land holdings are at high risk of malnutrition. These findings lend support to the theory that poverty is a very important determinant of malnutrition $(28,29)$.

In the group with severe malnutrition only $23 \%$ of children aged less than two years were still breast feeding compared to $44 \%$ in the control group. This confirms findings from several studies which have shown that early cessation of breast feeding is a risk factor for severe malnutrition $(30,31)$.

Surprisingly there was no association between nutrition knowledge of the caretakers/mothers and nutrition status of their children. Knowledge of weaning, duration of breastfeeding and frequency of feeding were similar in both groups. In a similar study in Nairobi, Kenya, Waihenya and colleagues(32) found that children were still at high risk of malnutrition despite adequate nutrition knowledge by the mothers. Willingness and ability to translate this nutrition knowledge into action is crucial in reducing levels of malnutrition(33).

In this case control study we have explored the socioeconomic risk factors for severe protein energy malnutrition in children attending Mulago Teaching Hospital in Kampala, Uganda. The risk factors include early cessation of breastfeeding, failure to complete the primary course of immunisation, and coming from an economically disadvantaged household. Specifically children from landless households, without any livestock and living in mud walled dwellings were at higher risk of malnutrition. Occupation, marital status and education level of the mothers did not seem to have a significant influence on nutrition status.

Despite Uganda's impressive political and economic recovery, childhood malnutrition is still a problem, with children from poor households bearing the brunt. Programmes aimed at poverty alleviation, promotion of immunisation and breast feeding will go a long way in improving nutrition status of our children.

\section{REFERENCES}

1. Statistics Department (Uganda) and Macro International Inc. Uganda Demographic Health Survey 1995; Calverton, Maryland; Uganda Ministry of Finance and Economic Planning; 1996; 12131.

2. Kikafunda J.K., Walker A.F., Collet D. and Tumwine J.K. Risk factors for early childhood malnutrition in Uganda. Paediatrics 1998; 10(e45): 1- 9.

3. USA Agency for International Development AFR/SD/HRD and G/PHN/HN. Nutrition of infants and young children in Uganda, $1995 ; 34-35$

4. Van Den Broeck J, Eeckels R, Vuylsteke J. Influence of nutrition status on child mortality in rural Zaire. Lancet 1993; 1341:14911495.

5. Beau J. P., Garenne M. and Drop B. Diarrhoea and nutrition status as risk factors for mortality in Dakar hospital. J. trop. Paediat. 1987; 33: 4-7.

6. Ogbeide O. and Osuhor P.C. The morbidity and mortality patterns among malnourished children in Benin city, Nigeria. Trop. Doct. 1984; 14:178-180.

7. Shah N., Ramankutty V., Premila P.G. and Sathy N. Risk factors for severe pneumonia in children in South Korea. A hospital based case control study. J. trop. Paediat. 1994; 40: 201-6 
8. Cravioto J. and De Licardie E.R. Mental performance in school age children: findings after recovery from early severe malnutrition. Amer. J. Dis. Child. 1970; 120: 404-410

9. Jitta J., Migadde M. and Mudusu J. Determinants of malnutrition in underfives in Uganda: An in depth secondary analysis of Uganda demographic and health Survey (188/89) data. Kampala Uganda: Ministry of Health and Child Health Development Centre, Makerere University, 1992: 24-107.

10. Wellcome Trust Working Party. Classification of infantile malnutrition. Lancet 1970; 2: 302-303.

11. Kirkwood RB Sampling methods Medical Statistics Osney Mead, Oxford: Blackwell Science Ltd; 1997:167-172.

12. Fleiss J.L. Statistical methods for rates and proportions, 2nd ed. New York, NY John Wiley and Sons; 1981: 38-45.

13. United Nations. How to weigh and measure children: Assessing the nutritional status of young children in household surveys. New York, NY: United Nations, 1986.

14. Ugwegbute AC Weaning practices and weaning foods of the Hausa, Yorubas and Ibos of Nigeria. Ecol Food Nutr, 1991; 26:139-153.

15. Dean A.G., Dean J.A. and Coulombier D., et al Epi info. Version 6.0: word processing data base and statistics programme for public health on IBM compatible microcomputers. Centres for Disease Research, Control and Prevention, Atlanta, Georgia, USA, 1997.

16. Vella V., Tomkins A., Borghesi G.B., Mighori G.B., Adriko B.C. and Crevatin E. Determinants of child nutrition in North West Uganda. Bull Wld Hlth Org. 1992; 70: 637-653.

17. Nhembe M. and Waterston T. Causes of malnutrition in Harare hospital: a case control study. Cent. Afr. J. Med. 1984; 30:97-101.

18. Oyedejo G.A., Olamijulo S.K. and Osinaike A.I., et al Secular trends in growth of children aged 0-6 years in a rural Nigerian community. Ann. trop. Paediat. 1996; 16:11-17.

19. Goodburn G.J. and Senapati S. Strategies educated mothers use to ensure health of their children. J. trop. Paediat. 1990; 36:17-23 .

20. Radebe B.Z., Brady J.P., Siziya S. and Todd H. Maternal risk factors for childhood malnutrition in Mazowe district of Zimbabwe Cent. Afr. J. Med. 1996; 42: 240-9.
21. Ahmed F. Nutritional situation in Dhaka. South East Asia J. trop. Med. Publ. Hlth. 1992; 23(suppl.3):59-64.

22. Mantulessy P.F., Asumi R. and Thamrin M.H. Nutrition situation in Metropolitan Jakarta. South East Asia J. trop. Med. Publ. Hlth. 1992; 23(suppl.3):3-16.

23. Himonga H.B. An approach to the detection of malnutrition in rural children using socioeconomic indices and level of education of mother as proxy. Med. J. Zambia. 1982; 16:17-21.

24. Ighogboga S.I. Some factors contributing to protein energy malnutrition in the middle belt of Nigeria. East Afr. Med. J. 1992; 69:566-571.

25. Vella V., Tomkins A. and Ndiku J. Determinants of nutritional status in western Uganda. J. trop. Paediat. 1995; 41: 89-98.

26. Sanders D. The origin of malnutrition in Zimbabwe. Cent. Afr. J. Med. 1982; 28:186-91.

27. Quinn V., Chiligo M. and Gittinger J.P. Malnutrition: household income and food security in rural Malawi. Health Policy and Planning. 1990; 5:139-148.

28. Spencer N. Poverty and child health in less developed countries. In: Poverty and Child Health; Oxford, UK and New York, NY: Radcliffe Medical Press, 1996: 74-94

29. Majumder A.K. and Islam S.M.S. Socioeconomic and environmental determinants of child survival in Bangladesh. $J$. Biosoc. Sci. 1993; 25:311-318.

30. Serventi M., Dal-Lago A.M. and Kimaro D.N. Early cessation of breast feeding as a major cause of severe malnutrition in under twos: a tropical based study in Dodoma region in Tanzania. East Afr. Med. J. 1995; 72:132-134.

31. Coulter J.B., Omer M.I. and Suliman G.I. Protein energy malnutrition in northern Sudan. Prevalence, socioeconomic factors and family background. Ann. trop. Paediat. 1988; 8:96-102.

32. Waihenya W.E., Kogi-Maku W. and Muita J.W. Maternal nutritional knowledge and nutritional status of pre-school children in a Nairobi slum. East Afr. Med. J. 1996; 73:419-423.

33. Jalil F. The principles and strategic steps of a simple nutrition message. Acta Paediatrica; Scand. (Suppl.) 1991; 374: 160-167. 